\title{
Calorimetric Properties of Some Alkali Pentaborate Hydrates From 15 to $370{ }^{\circ} \mathrm{K}$
}

\author{
George T. Furukawa, Martin L. Reilly, and Jeanette H. Piccirelli*
}

(February 24, 1964)

\begin{abstract}
Measurements of the heat capacity of ammonium pentaborate tetrahydrate $\left(\mathrm{NH}_{4} \mathrm{~B}_{5} \mathrm{O}_{8} \cdot 4 \mathrm{H}_{2} \mathrm{O}\right)$, potassium pentaborate tetrahydrate $\left(\mathrm{KB}_{5} \mathrm{O}_{8} \cdot 4 \mathrm{H}_{2} \mathrm{O}\right)$, and sodium pentaborate pentahydrate $\left(\mathrm{NaB}_{5} \mathrm{O}_{8} \cdot 5 \mathrm{H}_{2} \mathrm{O}\right)$ were made in the range of about 15 to $370{ }^{\circ} \mathrm{K}$ and the data were used to obtain a table of smoothed values of thermodynamic functions from 0 to $370^{\circ} \mathrm{K}$. The measurements on sodium pentaborate pentahydrate were terminated at $345^{\circ} \mathrm{K}$ because the temperature drifts that were observed above this temperature were considered to arise from gradual volatilization of the water of hydration.
\end{abstract}

\section{Introduction}

As a part of the program at the National Bureau of Standards to provide thermodynamic data on boron compounds, measurements of the heat capacity have been made on ammonium pentaborate tetrahydrate $\left(\mathrm{NH}_{4} \mathrm{~B}_{5} \mathrm{O}_{8} \cdot 4 \mathrm{H}_{2} \mathrm{O}\right)$, potassium pentaborate tetrahydrate $\left(\mathrm{KB}_{5} \mathrm{O}_{8} \cdot 4 \mathrm{H}_{2} \mathrm{O}\right)$, and sodium pentaborate pentahydrate $\left(\mathrm{NaB}_{5} \mathrm{O}_{8} \cdot 5 \mathrm{H}_{2} \mathrm{O}\right.$ ). (Henceforth, the abbreviations APT, PPT, and SPP will be used synonymously with the three respective alkali pentaborate hydrates.) These substances have the highest percentage of boric oxide $\left(\mathrm{B}_{2} \mathrm{O}_{3}\right)$ content of the commonly available hydrated borates. The data were used to obtain smoothed values of heat capacity, enthalpy, enthalpy function, entropy, Gibbs free energy, and Gibbs free energy function from 0 to $370^{\circ} \mathrm{K}$.

The hydrates of the alkali pentaborates investigated would be more properly formulated as $\left(\mathrm{NH}_{4}\right) \mathrm{H}_{4} \mathrm{~B}_{5} \mathrm{O}_{10} \cdot 2 \mathrm{H}_{2} \mathrm{O}, \mathrm{KH}_{4} \mathrm{~B}_{5} \mathrm{O}_{10} \cdot 2 \mathrm{H}_{2} \mathrm{O}$, and $\mathrm{NaH}_{4} \mathrm{~B}_{5^{-}}$ $\mathrm{O}_{10} \cdot 3 \mathrm{H}_{2} \mathrm{O}$. The "hydrated" pentaborate ion, $\mathrm{H}_{4} \mathrm{~B}_{5^{-}}$ $\mathrm{O}_{10}{ }^{-}$, consists of two six-atom rings lying in perpendicular planes joined by a common tetrahedrally coordinated boron atom [1]. ${ }^{1}$ Each of the four trigonal boron atoms is attached to two oxygen atoms in the ring and to a hydroxyl group

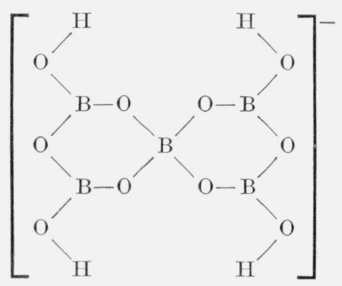

The water of hydration (two each in ammonium and potassium and three in sodium pentaborate) seems to be associated in some way with the oxygen atoms of the tetrahedral boron $[2,3]$. The dihydrate of

*Formerly Jeanette M. Henning.

Figures in brackets indicate the literature references at the end of this paper. the sodium compound has not been isolated [3]. The trihydrate of lithium pentaborate and the dihydrates of rubidium and cesium pentaborates have been observed [3]. The anhydrous compound $\mathrm{KB}_{5} \mathrm{O}_{8}$ is known [4] but the anhydrate of APT and SPP has not been isolated [3]. The thermodynamics of these and other hydrated polyborates should be of interest for comparison with hydrated polysilicates, polyphosphates, and other structurally related substances.

\section{Apparatus and Method}

The heat-capacity measurements were made in an adiabatic calorimeter similar in design to that described previously [5]. The sample container was suspended within the adiabatic shield system by means of a nylon string instead of the filling tube shown in the above reference. Details of the calorimeter used and its operation will be described in a subsequent publication.

Briefly, the sample was sealed in a copper container of about $125 \mathrm{~cm}^{3}$ capacity. The method for filling and the subsequent sealing of the container is shown schematically in figure 1. The sample was poured through the $1 / 4$ in. opening in the threaded member $\mathrm{G}$, which was later sealed by means of a $0.01 \mathrm{in}$. thick gold disk $\mathrm{F}$ and the accessory supporting components D and E. During the sealing process, the mushroom-shaped member $\mathrm{E}$ was held securely from turning by means of $\mathrm{A}$ and $\mathrm{B}$ so that the gold disk $\mathrm{F}$ would be pressed tightly, without turning, against the sealing edge of $\mathrm{G}$. The polished ridge on E decreased the "turning" friction between D and E. The screw-cap D was tightened against E by turning the knurled knob of wrench $\mathrm{C}$. When the container was sealed, the sealing assembly (A, B, C, and $\mathrm{H}$ ) was removed. Previous tests on simulated systems have shown that the seal was vacuum tight under the conditions of temperature cycling in the temperature range of the measurements and that the gold disk could be used three or four times or more without leakage. In addition a helium-gas leak detector was used to test the screw-cap seal with each sample through the auxiliary tube I. 


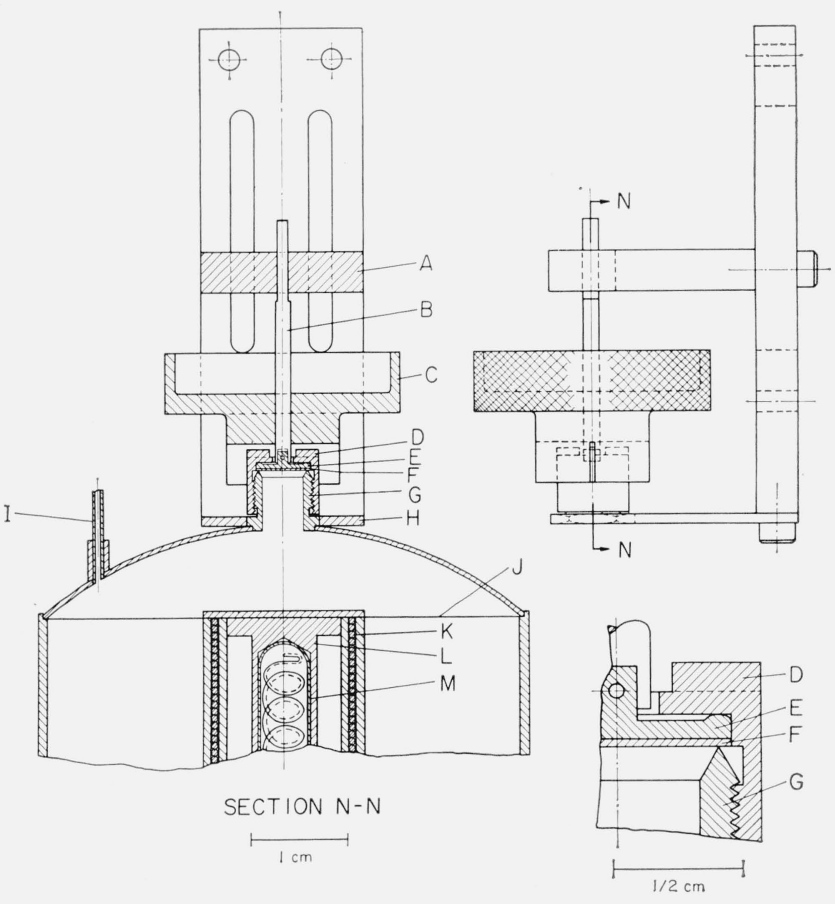

FIgurE 1. Screw-cap seal and sealing assembly for the sample container

A. Adjustable arrest with slot to keep rod B from turning. C. Wrench for turning screw-cap D

E. Mushroom-shaped plate that presses the gold gasket $\mathrm{F}$ against the sealing edge of the threaded tube $G$. Rod B prevents $E$ from turning.

$H$. Wrench held during the sealing process against a wrench flat at the base of $G$. I. Tinned copper tube for testing the screw-cap seal for vacuum and for the final sealing.

J. Top edge of radially arranged, tinned copper vanes. $\mathrm{K}$. Heater wire for the calorimeter vessel.

L. Copper case for the platinum thermometer case M.

The final seal was made by pinching and cutting the $1 / 16$ in. copper tubing I which was previously tinned on both inner and outer surfaces. The pinching was done over about $1 / 2$ in. of the tubing and a hot soldering tool was applied along the pinched portion of the tubing so that the tin on the inner surface would form a tight seal before the cutting was done at the pinched portion. Additional solder was applied at the cut edge as an added precaution against leakage.

In order to attain a rapid temperature equilibrium, tinned copper vanes were arranged radially from the central well to the outer wall of the container and held in place by a thin coating of pure tin applied to the inner surfaces. The radially arranged vanes were terminated in the plane indicated by $\mathrm{J}$ in figure 1 to permit easy distribution of sample when poured through the opening in G. A small quantity of helium gas was also sealed in with the sample to facilitate temperature equilibrium. The central well contained a heater-platinum resistance thermometer assembly (shown as $\mathrm{K}, \mathrm{L}$, and $\mathrm{M}$ in fig. 1).

The outer surface of the container and the adjacent inner surface of the adiabatic shield, within which the container was suspended by means of a nylon string, were gold plated and polished to minimize radiative heat transfer. The space around the container and shield was evacuated to a pressure of $10^{-5}$ torr or less $(1$ torr $=1 / 760 \mathrm{~atm}=1 \mathrm{~mm} \mathrm{Hg})$ to make negligible the heat transfer by gaseous conduction and convection. During the heat-capacity experiments the temperature of the shield was maintained as close as possible to that of the container surface by means of shield heaters and constantanChromel-P differential thermocouples. Two sets of thermocouples, one of three junctions and the other of two, and three individual heaters were used in the control of the adiabatic shield and lead-wire temperatures.

The electrical power input was measured by means of a Wenner potentiometer in conjunction with a standard cell, volt box, and standard resistor. The volt box was assembled from two standard resistors, 100 and 10,000 ohms, the voltage being measured across the $100-0 h m$ resistor. Since this is a relatively low-resistance voltage box, the resistance of the potential leads to the calorimeter heater was determined as a function of temperature. Over the temperature range of measurements, the volt-box "factor" changed up to 2 to 3 parts in 10,000 because of the change in the resistance of the potential leads with temperature. The volt-box factor was determined to better than 1 part in $10^{5}$.

The time interval of heating was measured by means of a precision timer operated on a $60 \mathrm{~Hz}$ frequency based on a $100 \mathrm{kHz}$ quartz oscillator maintained at the National Bureau of Standards. The oscillator is stable to $0.5 \mathrm{ppm}$. The timer was compared periodically with seconds signals based also on the $100 \mathrm{kHz}$ quartz oscillator. The timer deviations were never greater than 0.02 sec per heating period, which was never less than $2 \mathrm{~min}$.

Temperatures were measured by means of a platinum-resistance thermometer and a high-precision Mueller bridge. The thermometer was calibrated by the Temperature Physics Section of the NBS. The calibration above $90^{\circ} \mathrm{K}$ was in accordance with the 1948 International Practical Temperature Scale [6], and between 10 and $90{ }^{\circ} \mathrm{K}$ in accordance with the NBS-1955 provisional scale, which is maintained by a set of platinum-resistance thermometers that had been compared with a helium-gas thermometer.

At the Tenth General Conference held in 1954, the General Conference on Weights and Measures adopted a new definition of the thermodynamic temperature scale by assigning the temperature $273.16^{\circ} \mathrm{K}$ to the triple-point temperature of water [6]. The provisional temperature scale as it is presently maintained at the National Bureau of Standards, and referred to as degrees K (NBS-1955), is numerically $0.01 \mathrm{deg}$ lower than the former NBS-1939 scale [7]. The observed temperatures given in this paper conform with these new definitions of the temperature scales. The temperatures in degrees Kelvin above $90{ }^{\circ} \mathrm{K}$ were obtained by adding $273.15 \mathrm{deg}$ to the temperatures in degrees 
Celsius (International Practical Temperature Scale $[6])$.

The 1961 atomic weights based on $\mathrm{C}^{12}$ were used to convert the mass of samples investigated to molal basis [8].

\section{Analysis of Experimental Measurements}

The measurements of heat capacity were made in the range of about 15 to $370{ }^{\circ} \mathrm{K}$. Two sets of measurements were made, one on the container filled with sample and the other on the empty container. The usual precaution was observed to maintain the temperature increment of heating sufficiently small to minimize the correction for curvature of the heat-capacity function. The curvature correction was made wherever significant according to the procedure previously described [9].

After making the curvature corrections for the two sets of measurements, the heat-capacity values of the empty container were plotted on a large scale as deviations from approximate empirical equations. Smoothed values of the heat capacity at equally spaced integral temperatures were then obtained by combining the smooth deviation curves and the empirical equations. The temperature ranges of the empirical equations were overlapped and the values that joined most smoothly were selected. The smoothness of the tabular values was checked by examining the smoothness of the third and fourth differences. Wherever necessary a numerical smoothing process was employed [10].

The net heat capacities (heat capacity of the sample) were obtained by subtracting the heat capacity of the empty container from that of the container plus sample at corresponding temperatures. The values of heat capacity of the empty container were obtained by interpolation in the smoothed table described above. The net heat capacities were corrected for any differences in the mass of the container in the two sets of measurements. Corrections were made also wherever significant for the heat capacity of helium gas in the container. The net values of the heat capacity were then finally converted to molal basis [8] which are referred to in the following sections of this paper as "observed values of the heat capacity." The heat capacity of the samples in these measurements was $80 \pm 3$ percent of the "gross" over the entire range of the measurements.

Smoothed values of the heat capacity of each substance were then obtained at equally-spaced integral temperatures by plotting on a large scale the deviations of the observed values from empirical equations and following the procedures similar to those previously outlined for the measurements on the empty container. Debye heat capacity functions, fitted to the experimental values at the lower temperatures, were used for extrapolation to $0{ }^{\circ} \mathrm{K}$.

The thermodynamic properties for each substance were derived from the smoothed values of the heat capacity by procedures previously described [11].

\section{Samples}

The pentaborate samples obtained from the Pacific Coast Borax Company were in the form of fine crystals. Chemical analyses supplied with the sample are given in tables 1, 2, and 3. Analyses for $\mathrm{B}_{2} \mathrm{O}_{3}$, alkali oxide, and water were independently made on the samples by R. A. Paulson of the Applied Analytical Research Section of the Bureau. These results are summarized also in tables 1,2 , and 3 for comparison. The two sets of analyses are in fair agreement.

The ammonia in AP'T was analyzed by distilling the ammonia from a sample placed in a Kjeldahl apparatus and titrating with $0.1 N$ hydrochloric acid solution. The hydrochloric acid solution was standardized with single-crystal ammonium dihydrogen phosphate from which the ammonia was distilled from the Kjeldahl apparatus in the same manner as the AP'T sample.

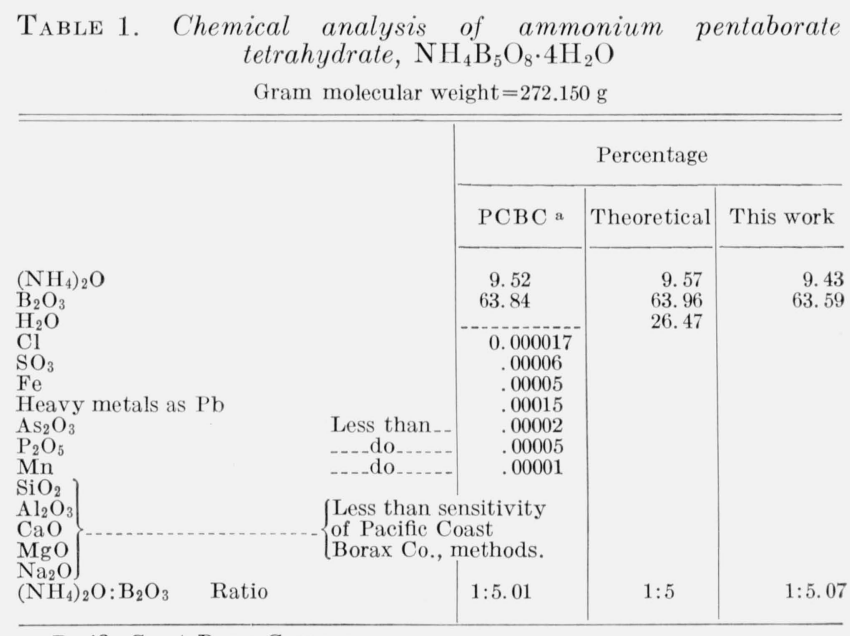

a Pacific Coast Borax Company.

TABLE 2. Chemical analusis of potassium pentaborate tetrahydrate, $\mathrm{KB}_{5} \mathrm{O}_{8} \cdot 4 \mathrm{H}_{2} \mathrm{O}$

Gram molecular weight $=293.214 \mathrm{~g}$

\begin{tabular}{|c|c|c|c|c|c|}
\hline & & \multicolumn{4}{|c|}{ Percentage } \\
\hline & & \multirow[b]{2}{*}{$\mathrm{PCBC}^{\mathrm{a}}$} & \multirow[b]{2}{*}{ Theoretical } & \multicolumn{2}{|c|}{ This work } \\
\hline & & & & Observed & $\begin{array}{l}\text { Normal- } \\
\text { ized }\end{array}$ \\
\hline $\begin{array}{l}\mathrm{K}_{2} \mathrm{O} \\
\mathrm{B}_{2} \mathrm{O}_{3} \\
\mathrm{H}_{2} \mathrm{O} \\
\mathrm{Na}_{2} \mathrm{O} \\
\mathrm{Cl} \\
\mathrm{SO}_{3} \\
\mathrm{SiO}_{2} \\
\mathrm{Al}_{2} \mathrm{O}_{3} \\
\mathrm{~F}_{2} \mathrm{O}_{3} \\
\mathrm{CaO} \\
\mathrm{MgO} \\
\mathrm{As}_{2} \mathrm{O}_{3} \\
\mathrm{P}_{2} \mathrm{O}_{5} \\
\mathrm{~Pb} \\
\mathrm{Mn} \\
\mathrm{K}_{2} \mathrm{O}: \mathrm{B}_{2} \mathrm{O}_{3}\end{array}$ & $\begin{array}{l}\text { Less than- } \\
\text { Less than- } \\
\text { Ratio }\end{array}$ & $\begin{array}{c}16.21 \\
59.31 \\
\text { none } \\
0.008 \\
.0002 \\
.0038 \\
.0051 \\
.0003 \\
.0012 \\
.0005 \\
.0007 \\
.0009 \\
.0050 \\
0.0001 \\
1: 4.95\end{array}$ & $\begin{array}{l}16.06 \\
59.37 \\
24.57\end{array}$ & $\begin{array}{l}16.07 \\
59.18 \\
24.63\end{array}$ & $\begin{array}{l}16.09 \\
59.25 \\
24.66\end{array}$ \\
\hline \multicolumn{4}{|c|}{ Total of $\mathrm{K}_{2} \mathrm{O}, \mathrm{B}_{2} \mathrm{O}_{3}$, and $\mathrm{H}_{2} \mathrm{O}$} & 99.88 & 100.00 \\
\hline
\end{tabular}


TABLE 3. Chemical analysis of sodium pentaborate pentahydrate, $\mathrm{NaB}_{5} \mathrm{O}_{8} \cdot 5 \mathrm{H}_{2} \mathrm{O}$

Gram molecular weight $=295.117 \mathrm{~g}$

\begin{tabular}{|c|c|c|c|c|c|}
\hline & & \multicolumn{4}{|c|}{ Percentage } \\
\hline & & \multirow[b]{2}{*}{$\mathrm{PCBC}$ a } & \multirow[b]{2}{*}{ Theoretical } & \multicolumn{2}{|c|}{ This work } \\
\hline & & & & Observed & $\begin{array}{l}\text { Normal- } \\
\text { ized }\end{array}$ \\
\hline $\begin{array}{l}\mathrm{Na}_{2} \mathrm{O} \\
\mathrm{B}_{2} \mathrm{O}_{3} \\
\mathrm{H}_{2} \mathrm{O} \\
\mathrm{Cl} \\
\mathrm{SO}_{3} \\
\mathrm{SiO}_{2} \\
\mathrm{Al}_{2} \mathrm{O}_{3} \\
\mathrm{Fe}_{2} \mathrm{O}_{3} \\
\mathrm{CaO} \\
\mathrm{MgO} \\
\mathrm{P}_{2} \mathrm{O}_{5} \\
\mathrm{As}_{2} \mathrm{O}_{3} \\
\mathrm{~Pb} \\
\mathrm{Mn} \\
\mathrm{Na}_{2} \mathrm{O}: \mathrm{B}_{2} \mathrm{O}_{3}\end{array}$ & Ratio & $\begin{array}{c}10.59 \\
58.64 \\
0.0046 \\
.0014 \\
.0014 \\
.0047 \\
.0035 \\
.0080 \\
.0005 \\
.0041 \\
.0001 \\
.0015 \\
.00025 \\
1: 4.93\end{array}$ & $\begin{array}{l}10.50 \\
58.98 \\
30.52\end{array}$ & $\begin{array}{l}10.64 \\
58.54 \\
30.98\end{array}$ & $\begin{array}{l}10.62 \\
58.45 \\
30.93\end{array}$ \\
\hline \multicolumn{4}{|c|}{ Total of $\mathrm{Na}_{2} \mathrm{O}, \mathrm{B}_{2} \mathrm{O}_{3}$, and $\mathrm{H}_{2} \mathrm{O}$} & 100.16 & 100.00 \\
\hline
\end{tabular}

a Pacific Coast Borax Company.

The sodium and potassium in the samples were analyzed gravimetrically. The boron in the respective pentaborate was removed by evaporating to dryness six times with hydrochloric acid and methyl alcohol. The borate is removed in the process as volatile methylborate. The $\mathrm{NaCl}$ or the $\mathrm{KCl}$ formed was finally ignited at $700{ }^{\circ} \mathrm{C}$ and weighed.

The boron was analyzed as boric acid. A sample was dissolved in water and the $p \mathrm{H}$ adjusted to 7.0. Mannitol was added and the boric acid titrated with $0.1 \mathrm{~N} \mathrm{NaOH}$ solution which had been standardized with pure boric acid.

The water of hydration was determined by heating a sample in a muffle furnace at $450{ }^{\circ} \mathrm{C}$ until a constant weight was obtained. The loss of weight of the ammonium compound at the above temperature was more than the expected amount of water. An additional analysis made on the substance in a tube furnace with a stream of dry argon also showed excessive loss of mass. Ievin'sh et al. [12] found that the last trace of water of hydration was not removed in $\mathrm{APT}$ until about $250^{\circ} \mathrm{C}$ and that ammonia began to vaporize from about $140{ }^{\circ} \mathrm{C}$. No determination of the water was, therefore, obtained on APT.

The analyses on PPT and SPP were normalized to 100 percent shown in the last column of tables 2 and 3 , respectively. The low $\left(\mathrm{NH}_{4}\right)_{2} \mathrm{O}$ and $\mathrm{B}_{2} \mathrm{O}_{3}$ content in APT suggests that the impurity is $\mathrm{B}(\mathrm{OH})_{3}$. Similarly, in PPT the low $\mathrm{B}_{2} \mathrm{O}_{3}$ and high $\mathrm{H}_{2} \mathrm{O}$ content with almost the theoretical content of $\mathrm{K}_{2} \mathrm{O}$ suggest that the impurity is $\mathrm{B}(\mathrm{OH})_{3}$. (The $\mathrm{B}_{2} \mathrm{O}_{3}$ content is lower and $\mathrm{H}_{2} \mathrm{O}$ content higher in $\mathrm{B}(\mathrm{OH})_{3}$ than in APT, PPT, or SPP.) The high $\mathrm{Na}_{2} \mathrm{O}$, low $\mathrm{B}_{2} \mathrm{O}_{3}$, and high $\mathrm{H}_{2} \mathrm{O}$ content in the SPP sample indicate that the impurity is probably $\mathrm{Na}_{2} \mathrm{~B}_{4} \mathrm{O}_{7} \cdot 10 \mathrm{H}_{2} \mathrm{O}$ (borax). (Borax has a higher $\mathrm{Na}_{2} \mathrm{O}$, lower $\mathrm{B}_{2} \mathrm{O}_{3}$, and higher $\mathrm{H}_{2} \mathrm{O}$ content than SPP.) The percentages of the suspected impurities calculated on the bases of the alkali oxide, boric oxide, and water contents obtained in the chemical analyses are summarized in table 4.

Because of the closeness of the $\mathrm{B}_{2} \mathrm{O}_{3}$ content of $\mathrm{B}(\mathrm{OH})_{3}$ to that of PPT, the error in the analysis of $\mathrm{B}_{2} \mathrm{O}_{3}$ would indicate directly the uncertainty in the content of $\mathrm{B}(\mathrm{OH})_{3}$ impurity in PPT. The comparison of the literature values (range: 15 to $300^{\circ} \mathrm{K}$ ) of the heat capacity of $\mathrm{B}(\mathrm{OH})_{3}[13]$ with the observed values of the PPT sample showed that the heat capacity of $\mathrm{B}(\mathrm{OH})_{3}$ is at most about 17 percent higher than PP'T on the basis of mass. Considering also the uncertainty in the analysis of PPT for $\mathrm{B}_{2} \mathrm{O}_{3}$, the PPT sample was taken to be 100 percent pure in analyzing the experimental data.

The comparison of the observed heat capacity of the APT sample with that of $\mathrm{B}(\mathrm{OH})_{3}$ [13] showed that the heat capacity of the two materials differs generally within \pm 2 percent on the basis of mass. Therefore, the APT sample was also considered 100 percent pure in the analysis of the experimental data

TABLE 4. Percentages of the suspected impurities based on the analyses on alkali oxide, boric oxide and water contents

\begin{tabular}{|c|c|c|c|c|}
\hline \multirow{2}{*}{ Compound } & \multirow{2}{*}{ Impurity } & \multicolumn{3}{|c|}{ Method of Analysis } \\
\hline & & $\mathrm{M}_{2} \mathrm{O}$ & $\mathrm{B}_{2} \mathrm{O}_{3}$ & $\mathrm{H}_{2} \mathrm{O}$ \\
\hline $\begin{array}{l}\text { APT }- \\
\text { PPT - } \\
\text { SPP-- }\end{array}$ & $\begin{array}{l}\mathrm{B}(\mathrm{OH})_{3} \\
\mathrm{~B}(\mathrm{OH})_{3} \\
\mathrm{Na}_{2} \mathrm{~B}_{4} \mathrm{O}_{7} \cdot 10 \mathrm{H}_{2} \mathrm{O}\end{array}$ & $\begin{array}{r}1.4 \\
-0.2 \\
2.1\end{array}$ & $\begin{array}{l}4.8 \\
2.6 \\
2.4\end{array}$ & $\begin{array}{l}0 . \\
2 .\end{array}$ \\
\hline
\end{tabular}

No heat-capacity data on borax were found in the literature. The heat capacity of SPP and borax was assumed the same on the basis of mass.

\section{Results}

\subsection{Ammonium Pentaborate Tetrahydrate, $\mathrm{NH}_{4} \mathrm{~B}_{5} \mathrm{O}_{8} \cdot 4 \mathrm{H}_{2} \mathrm{O}$}

A $126.557 \mathrm{~g}$ sample of APT was investigated in the range 11 to $370{ }^{\circ} \mathrm{K}$. The observed values of molal heat capacity are given in table 5 , and plotted in figure 2. Values of molal heat capacity and derived thermodynamic functions were obtained at equally spaced integral temperatures. These are listed in table 6.

\subsection{Potassium Pentaborate Tetrahydrate, $\mathrm{KB}_{5} \mathrm{O}_{8} \cdot 4 \mathrm{H}_{2} \mathrm{O}$}

A $141.366 \mathrm{~g}$ sample of PPT was investigated from about 17 to $370{ }^{\circ} \mathrm{K}$. The observed values of molal heat capacity are listed in table 7 and plotted in figure 3 to show the general shape of the heatcapacity curve. Smoothed values of the heat capacity obtained from the experimental data and derived thermodynamic functions are listed in table 8 . 
TABLE 5. Observed heat capacities of ammonium pentaborate tetrahydrate $\left(\mathrm{NH}_{4} \mathrm{~B}_{5} \mathrm{O}_{8} \cdot 4 \mathrm{H}_{2} \mathrm{O}\right)$

Gram molecular weight $=272.150 \mathrm{~g}, T$ deg $\mathrm{K}=t \operatorname{deg} \mathrm{C}+273.15$

\begin{tabular}{|c|c|c|c|c|c|}
\hline $\begin{array}{l}\text { Run } \\
\text { No. }\end{array}$ & $T$ a & $C_{P} \mathrm{~b}$ & $\begin{array}{l}\text { Run } \\
\text { No. }\end{array}$ & $T$ a & $C_{P}$ b \\
\hline \multirow{9}{*}{1} & ${ }^{\circ} K$ & $J$ deg $^{-1}$ mole $e^{-1}$ & \multirow{10}{*}{4} & ${ }^{\circ} \mathrm{K}$ & $J$ deg ${ }^{-1}$ mole $e^{-1}$ \\
\hline & c 52.3798 & 82.092 & & 154.0512 & 216.64 \\
\hline & 55.4564 & 87.804 & & 158.8058 & 221.58 \\
\hline & 59.8250 & 95.826 & & 163.5319 & 226.65 \\
\hline & 64.6501 & 104.25 & & 168.2332 & 231.54 \\
\hline & 68.9856 & 111.18 & & 172.8415 & 236.31 \\
\hline & 73.0430 & 117. 29 & & 177.5292 & 241.08 \\
\hline & 77.3063 & 123.76 & & 182.2946 & 246.17 \\
\hline & 81. 7702 & 130.41 & & 186.9958 & 250.78 \\
\hline \multirow[t]{27}{*}{2} & 11.4684 & 4.268 & & 191.6386 & 255.56 \\
\hline & 12.2470 & 5. 041 & \multirow[t]{17}{*}{5} & 185.3702 & 248.91 \\
\hline & 12.9902 & 5.857 & & 188.8388 & 252.08 \\
\hline & 13. 7754 & 6.831 & & 193.3818 & 257.29 \\
\hline & 14.6079 & 7.881 & & 198.9176 & 262.78 \\
\hline & 15.5078 & 9.139 & & 205.4147 & 269. 22 \\
\hline & 16.4598 & 10.516 & & 211.7558 & 275.38 \\
\hline & 17.5058 & 12.118 & & 218.4874 & 282.04 \\
\hline & 18. 7824 & 14.174 & & 225.5958 & 289.18 \\
\hline & 20.1809 & 16.554 & & 232.5298 & 295. 51 \\
\hline & 21.5636 & 19.032 & & 239.3223 & 302.38 \\
\hline & 23.0268 & 21. 736 & & 246.0784 & 308.92 \\
\hline & 24.5876 & 24.749 & & 253. 7222 & 316.48 \\
\hline & 26.2042 & 29.964 & & 260.8091 & 322.92 \\
\hline & 27. 9198 & 31.402 & & 267.2680 & 328.97 \\
\hline & 29.9899 & 35.709 & & 273.6075 & 335.09 \\
\hline & 32.1900 & 40.385 & & 279.8340 & 340.69 \\
\hline & 34.2854 & 43.807 & & & \\
\hline & 36.6468 & 49.984 & \multirow[t]{8}{*}{6} & 277. 7998 & 338.07 \\
\hline & 39.7470 & 56.529 & & 285.7512 & 345.54 \\
\hline & 43.5102 & 64.396 & & 293.5821 & 352. 74 \\
\hline & 47.0718 & 71.681 & & 301.2508 & 359.45 \\
\hline & 50.7106 & 78.998 & & 308.7752 & 366.45 \\
\hline & 53.3932 & 84.159 & & 316.1723 & 373.00 \\
\hline & 56.3964 & 89.765 & & 323.4430 & 379.46 \\
\hline & 60.7088 & 97.628 & & 330.5918 & 385. 73 \\
\hline & & 126.60 & \multirow{13}{*}{7} & $\begin{array}{l}337.0318 \\
344.9387\end{array}$ & $\begin{array}{l}391.78 \\
397.97\end{array}$ \\
\hline \multirow{12}{*}{3} & $\begin{array}{l}79.7048 \\
83.7367\end{array}$ & $\begin{array}{l}120.00 \\
132.96\end{array}$ & & $\begin{array}{l}344.958 \\
352.4211\end{array}$ & 404.64 \\
\hline & 87.8826 & 138.91 & & 359.6954 & 410.85 \\
\hline & 91.8441 & 144.06 & & 366.8040 & 417. 64 \\
\hline & 95.6642 & 148.85 & & & \\
\hline & 99. 3594 & 153.49 & & 127.8625 & 187.44 \\
\hline & 102.9710 & 157.99 & & 134.7264 & 195. 30 \\
\hline & 106.5092 & 162.33 & & 141.6874 & 203. 00 \\
\hline & 110.2500 & 167.37 & & 147. 7845 & 209. 64 \\
\hline & 114.1990 & 171.64 & & 153.2160 & 215.54 \\
\hline & 118.1925 & 176.34 & & 158.4969 & 221.19 \\
\hline & 122.2382 & 181.13 & & & \\
\hline & 126.1821 & 185.61 & & & \\
\hline
\end{tabular}

a $T$ is the mean temperature of the heating interval.

$C_{P}$ is the observed mean heat eapacity over the interval.

e The temperatures given are believed to be accurate to $0.01^{\circ} \mathrm{K}$. The figures beyond the second decimal are significant only insofar as small temperature differences are concerned.

\subsection{Sodium Pentaborate Pentahydrate, $\mathrm{NaB}_{5} \mathrm{O}_{8} \cdot 5 \mathrm{H}_{2} \mathrm{O}$}

A $177.320 \mathrm{~g}$ sample of SPP was investigated. Downward temperature drifts were observed in the measurements above $345^{\circ} \mathrm{K}$. Blasdale and Slansky [14] reported that SPP could be heated in an open container up to $70{ }^{\circ} \mathrm{C}$ without appreciable loss in weight, but when heated to $116{ }^{\circ} \mathrm{C}$ it formed a viscous liquid and began to lose water. On the bases of the observations of Blasdale and Slansky and of the high sensitivity of the calorimeter to any heat effects $(0.0001 \mathrm{~W}$ or smaller), it seems likely that the downward temperature drifts observed are due to gradual dehydration of the SPP sample. Therefore, the data above $345^{\circ} \mathrm{K}$ are considered inaccurate and are not reported. The observed molal values of heat capacity are given in table 9 and plotted in figure 4. The derived thermodynamic properties are listed in table 10 from 0 to $345^{\circ} \mathrm{K}$.

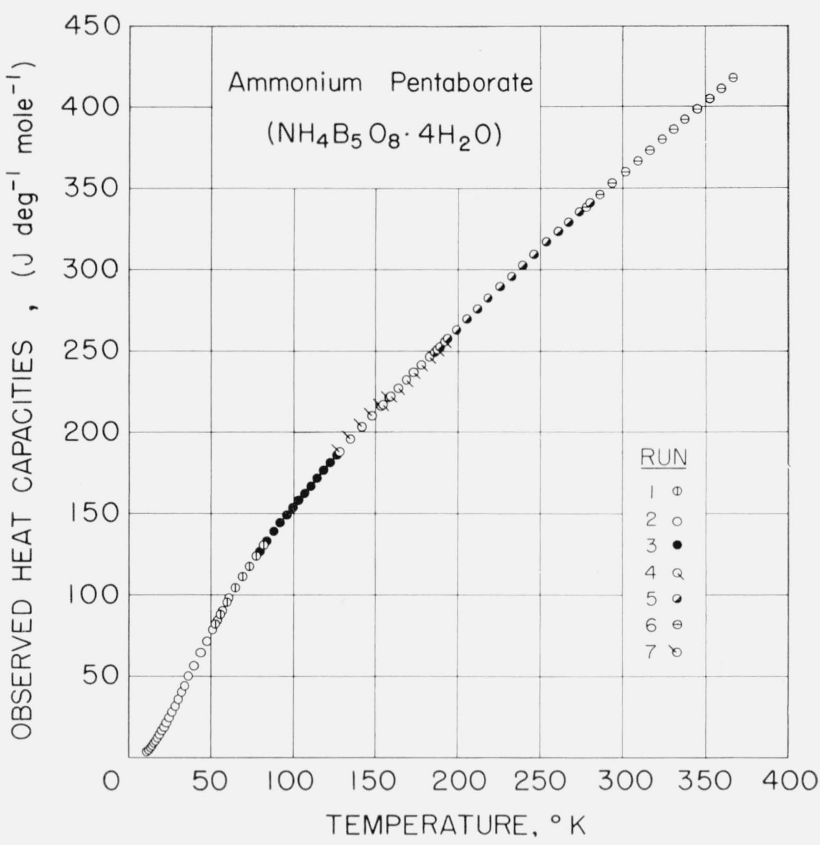

Figure 2. Observed heat capacities of ammonium pentaborate tetrahydrate, $\mathrm{NH}_{4} \mathrm{~B}_{5} \mathrm{O}_{8} \cdot 4 \mathrm{H}_{2} \mathrm{O}$.

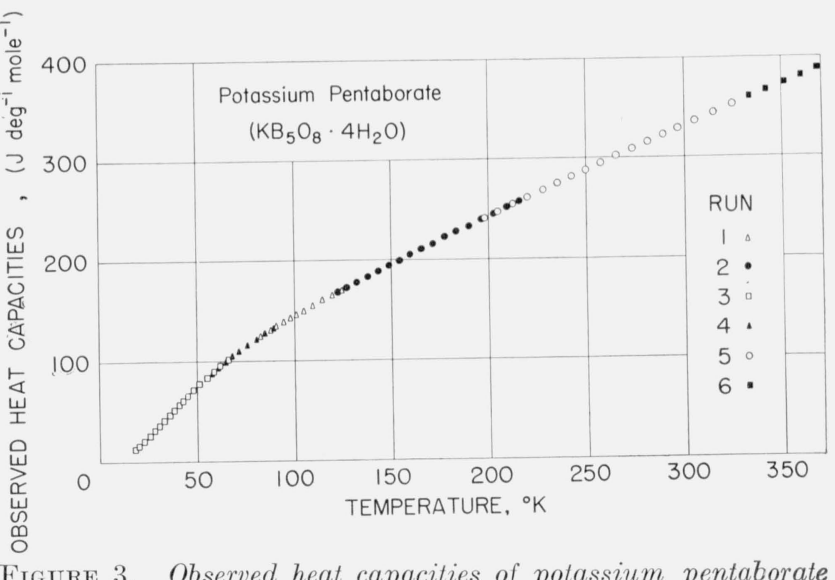

FIgURE 3. Observed heat capacities of potassium pentaborate tetrahydrate, $\mathrm{KB}_{5} \mathrm{O}_{8} \cdot 4 \mathrm{H}_{2} \mathrm{O}$.

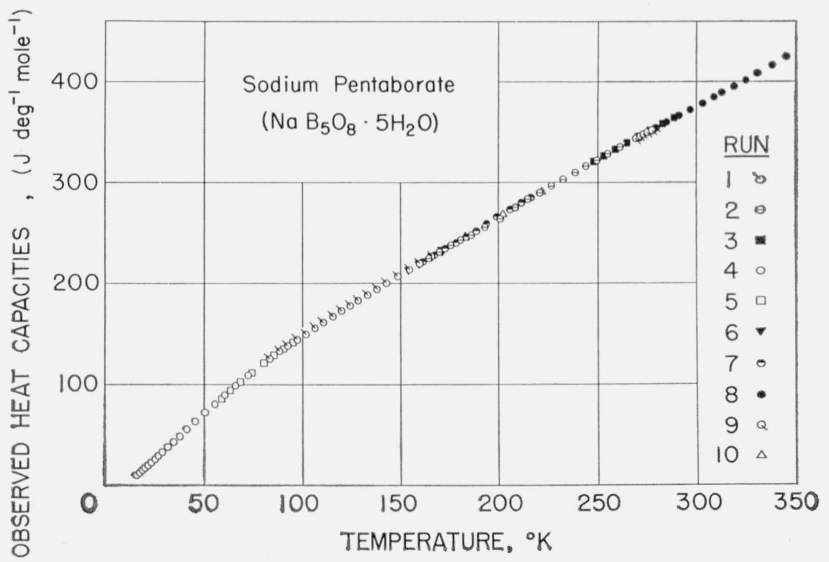

FIGURE 4. Observed heat capacities of sodium pentaborate pentahydrate, $\mathrm{NaB}_{5} \mathrm{O}_{8} \cdot 5 \mathrm{H}_{2} \mathrm{O}$. 
TABLE 6. Molal thermal functions for ammonium pentaborate tetrahydrate $\left(\mathrm{NH}_{4} \mathrm{~B}_{5} \mathrm{O}_{8} \cdot 4 \mathrm{H}_{2} \mathrm{O}\right)$

Gram molecular weight $=272.150 \mathrm{~g}, T$ deg $\mathrm{K}=t \operatorname{deg} \mathrm{C}+273.15$

\begin{tabular}{|c|c|c|c|c|c|c|}
\hline$T$ & $C_{P}$ & $\left(H_{T}-H_{0}^{C}\right)$ & $\frac{\left(H_{T}-H_{0}^{C}\right)}{T}$ & $S_{T}$ & $-\left(G_{T}-H_{0}^{C}\right)$ & $\frac{-\left(G_{T}-H_{0}^{C}\right)}{T}$ \\
\hline${ }^{\circ} K$ & $J / d e g$ & $J$ & $J /$ deg & $J /$ deg & $J$ & $J /$ deg \\
\hline 0.00 & 0.000 & 0.000 & 0.000 & 0.000 & 0.000 & 0.000 \\
\hline 5.00 & 0.327 & 0.405 & 0.081 & 0.107 & 0.131 & 0.026 \\
\hline 10.00 & 2. 607 & 6.532 & 0.653 & 0.870 & 2.165 & 0.216 \\
\hline 15.00 & 8. 224 & 32.215 & 2.148 & 2.876 & 10.924 & 0.728 \\
\hline 20.00 & 16. 386 & 93.166 & 4. 658 & 6. 326 & 33.363 & 1. 668 \\
\hline 25.00 & 25. 512 & 197.30 & 7.892 & 10.936 & 76.105 & 3. 044 \\
\hline 30.00 & 35. 709 & 350.05 & 11. 668 & 16.478 & 144.29 & 4.810 \\
\hline 35.00 & 46. 371 & 555.11 & 15.860 & 22.779 & 242.15 & 6.918 \\
\hline 40.00 & 57.033 & 813.76 & 20.344 & 29.670 & 373.06 & 9.326 \\
\hline 45.00 & 67.437 & 1125.0 & 25. 001 & 36.991 & 539.56 & 11.990 \\
\hline 50.00 & 77. 514 & 1487.6 & 29.752 & 44.621 & 743.49 & 14.870 \\
\hline 55.00 & 87.128 & 1899.4 & 34.535 & 52.464 & 986.13 & 17. 930 \\
\hline 60.00 & 96.263 & 2358.1 & 39.301 & 60.440 & 1268.3 & 21.139 \\
\hline 65.00 & 105.01 & 2861.5 & 44. 024 & 68.495 & 1590.7 & 24.472 \\
\hline 70.00 & 112. 74 & 3406.2 & 48. 660 & 76.564 & 1953.3 & 27. 905 \\
\hline 75.00 & 120.20 & 3988.6 & 53.181 & 84.598 & 2356.2 & 31.417 \\
\hline 80.00 & 127.77 & 4608.6 & 57.608 & 92.598 & 2799.2 & 34.991 \\
\hline 85.00 & 134.71 & 5265.0 & 61.941 & 100.55 & 3282.1 & 38.613 \\
\hline 90.00 & 141.61 & 5955.9 & 66.176 & 108.45 & 3804.7 & 42.274 \\
\hline 95.00 & 148. 07 & 6680.2 & 70. 318 & 116. 28 & 4366.5 & 45. 964 \\
\hline 100.00 & 154.32 & 7436.3 & 74.363 & 124.04 & 4967.4 & 49. 674 \\
\hline 105.00 & 160.46 & 8223.3 & 78.317 & 131. 71 & 5606.8 & 53. 398 \\
\hline 110.00 & 166.50 & 9040.7 & 82.188 & 139. 32 & 6284.4 & 57.131 \\
\hline 115.00 & 172.42 & 9888.1 & 85. 983 & 146.85 & 6999.9 & 60.868 \\
\hline 120.00 & 178.26 & 10765 & 89. 707 & 154. 31 & 7752.8 & 64.607 \\
\hline 125.00 & 184.04 & 11671 & 93.365 & 161.71 & 8542.9 & 68.343 \\
\hline 130.00 & 189. 76 & 12605 & 96.962 & 169.04 & 9369.8 & 72.075 \\
\hline 135.00 & 195. 42 & 13568 & 100.50 & 176. 31 & 10233 & 75.801 \\
\hline 140.00 & 201.01 & 14559 & 103. 99 & 183. 51 & 11133 & 79.519 \\
\hline 145.00 & 206.55 & 15578 & 107.44 & 190. 66 & 12068 & 83.229 \\
\hline 150.00 & 212.02 & 16625 & 110.83 & 197. 76 & 13039 & 86.928 \\
\hline 155.00 & 217.44 & 17698 & 114.18 & 204.80 & 14046 & 90.617 \\
\hline 160.00 & 222.81 & 18799 & 117.49 & 211. 79 & 15087 & 94.295 \\
\hline 165.00 & 228.13 & 19926 & 120.77 & 218. 73 & 16163 & 97.960 \\
\hline 170.00 & 233. 26 & 21080 & 124. 00 & 225.61 & 17274 & 101. 61 \\
\hline 175.00 & 238.60 & 22259 & 127.20 & 232.45 & 18420 & 105.25 \\
\hline 180.00 & 243.76 & 23465 & 130.36 & 239.25 & 19599 & 108.88 \\
\hline 185.00 & 248.86 & 24697 & 133.50 & 245. 99 & 20812 & 112.50 \\
\hline 190.00 & 253. 92 & 25954 & 136. 60 & 252.70 & 22059 & 116.10 \\
\hline 195.00 & 258.92 & 27236 & 139.67 & 259.36 & 23339 & 119.69 \\
\hline 200.00 & 263.87 & 28543 & 142.71 & 265. 98 & 24652 & 123.26 \\
\hline 205. 00 & 268. 79 & 29875 & 145. 73 & 272.55 & 25998 & 126.82 \\
\hline 210.00 & 273.65 & 31231 & 148. 72 & 279.09 & 27378 & 130.37 \\
\hline 215.00 & 278.55 & 32611 & 151.68 & 285.58 & 28789 & 133.90 \\
\hline 220.00 & 283.44 & 34016 & 154.62 & 292.04 & 30233 & 137.42 \\
\hline 225.00 & 288.32 & 25446 & 157.54 & 298.47 & 31710 & 140.93 \\
\hline 230.00 & 293.20 & 36899 & 160.43 & 304.86 & 33218 & 144.43 \\
\hline 235.00 & 298.04 & 38377 & 163.31 & 311.22 & 34758 & 147. 91 \\
\hline 240.00 & 302.87 & 39880 & 166.17 & 317.54 & 36330 & 151.38 \\
\hline 245.00 & 307.68 & 41406 & 169. 00 & 323.84 & 37934 & 154.83 \\
\hline 250.00 & 312.46 & 42956 & 171.83 & 330.10 & 39568 & 158.27 \\
\hline 255.00 & 317.21 & 44531 & 174. 63 & 336.33 & 41234 & 161.70 \\
\hline 260.00 & 321.93 & 46129 & 177.42 & 342.54 & 42932 & 165.12 \\
\hline 265.00 & 326.63 & 47750 & 180.19 & 348.72 & 44660 & 168.53 \\
\hline 270.00 & 331.29 & 49395 & 182. 94 & 354.86 & 46419 & 171.92 \\
\hline 273.15 & 334.22 & 50443 & 184.67 & 358.72 & 47543 & 174.05 \\
\hline 275.00 & 335.93 & 51063 & 185.68 & 360.99 & 48208 & 175.30 \\
\hline 280.00 & 340.54 & 52754 & 188.41 & 367.08 & 50029 & 178.67 \\
\hline 285.00 & 345.13 & 54468 & 191.12 & 373.15 & 51879 & 182.03 \\
\hline 290.00 & 349.68 & 56205 & 193. 81 & 379.19 & 53760 & 185. 38 \\
\hline 295.00 & 354.22 & 57965 & 196.49 & 385.21 & 55671 & 188.72 \\
\hline 298.15 & 357.06 & 59085 & 198.17 & 388. 98 & 56890 & 190.81 \\
\hline 300.00 & 358.72 & 59747 & 199.16 & 391.20 & 57612 & 192.04 \\
\hline 305.00 & 363.20 & 61552 & 201.81 & 397.16 & 59583 & 195.35 \\
\hline 310.00 & 367.65 & 63379 & 204.45 & 403.11 & 61584 & 198.66 \\
\hline 315.00 & 372.08 & 65229 & 207.08 & 409.02 & 63614 & 201.95 \\
\hline 320.00 & 376.49 & 67100 & 209. 69 & 414. 92 & 65674 & 205. 23 \\
\hline 325.00 & 380.87 & 68993 & 212.29 & 420.79 & 67763 & 208.50 \\
\hline 330.00 & 385.22 & 70909 & 214.87 & 426.64 & 69882 & 211.76 \\
\hline 335.00 & 389.57 & 72846 & 217.45 & 432.46 & 72029 & 215.01 \\
\hline 340.00 & 393.90 & 74804 & 220.01 & 438.27 & 74206 & 218.25 \\
\hline 345.00 & 398. 21 & 76785 & 222.56 & 444.05 & 76412 & 221.48 \\
\hline & 402.53 & 78786 & 225.10 & 449.81 & 78647 & 224.71 \\
\hline 355.00 & 406.85 & 80810 & 227.63 & 455.55 & 80910 & 227.92 \\
\hline 360.00 & 411.20 & 82855 & 230.15 & 461.27 & 83202 & 231. 12 \\
\hline 365.00 & 415.64 & 84922 & 232.66 & 466.97 & 85523 & 234.31 \\
\hline 370.00 & 420.19 & 87012 & 235.17 & 472.66 & 87872 & 237.49 \\
\hline 373.15 & 423.14 & 88340 & 236.74 & 476.23 & 89366 & 239.49 \\
\hline
\end{tabular}

$H_{0}^{C}$ apply to the reference state of the solid at $0{ }^{\circ} \mathrm{K}$
TABLE 7. Observed heat capacities of potassium pentaborate tetrahydrate $\left(\mathrm{KB}_{5} \mathrm{O}_{8} \cdot 4 \mathrm{H}_{2} \mathrm{O}\right)$

Gram molecular weight $=293.214 \mathrm{~g}, T \operatorname{deg} \mathrm{K}=t \operatorname{deg} \mathrm{C}+273.15$

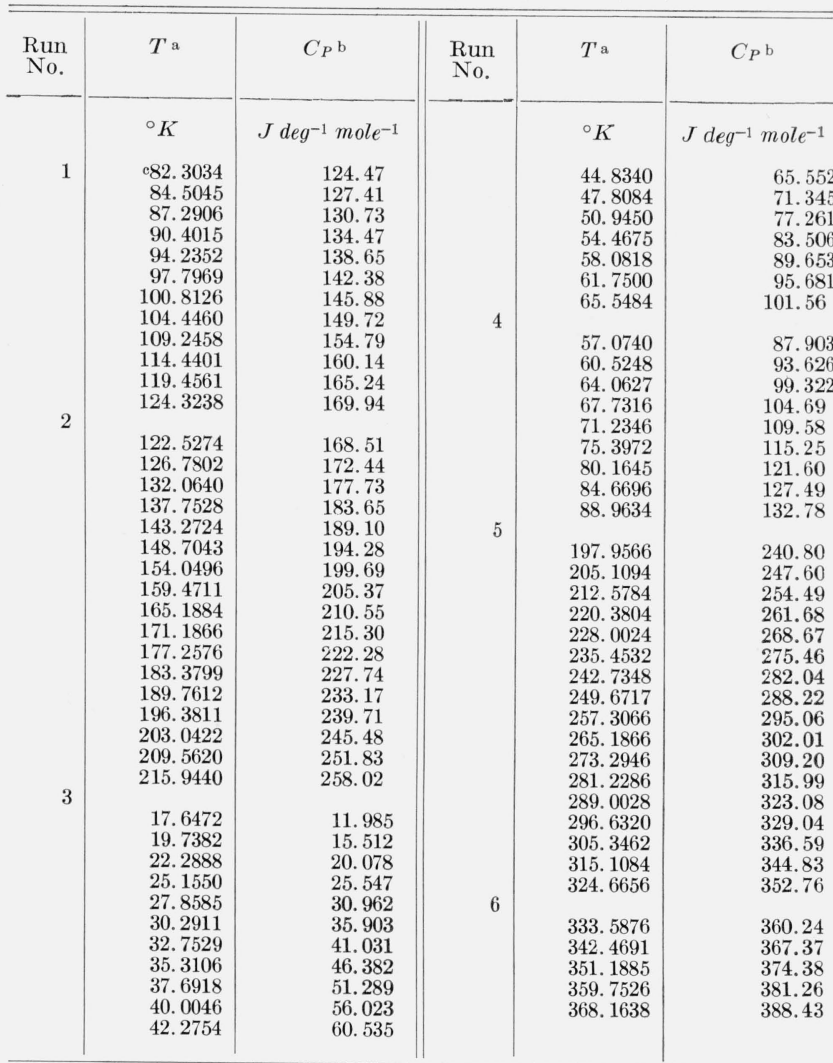

a $T$ is the mean temperature of the heating interval

b $C_{P}$ is the observed mean heat capacity over the interval.

c The temperatures given are believed to be accurate to $0.01^{\circ} \mathrm{K}$. The figures beyond the second decimal are significant only insofar as small temperature

\section{Discussion}

In a series of papers Staveley et al. $[15,16,17]$ investigated the contribution of the torsional or rotational motion of the ammonium ion to the heat capacity of ammonium salts with large symmetrical anions. By investigating the heat capacity of the ammonium and the corresponding isomorphous potassium and rubidium salts the heat-capacity contribution from the torsional oscillation or rotation of the ammonium ion was estimated by subtraction, assuming that the heat-capacity contributions from $\mathrm{Cp}-\mathrm{Cv}$, internal and torsional motions of the anion, and the lattice vibrations were the same in the two salts. (Hereafter the torsional or rotational heat capacity contribution of the $\mathrm{NH}_{4}{ }^{+}$ ion will be designated $\Delta C_{\tau}\left(\mathrm{NH}_{4}^{+}\right)$.) The small contribution from the internal motions of the $\mathrm{NH}_{4}{ }^{+}$ion was calculated using the assigned frequencies of Wagner and Hornig [18]. If the residual heat capacity obtained had a limiting value of $\frac{3}{2} R$ or $3 R$, a free rotation or a classical torsional oscillation, respectively, was suggested. For restricted rotator behavior a rise to a maximum 
TABLE 8. Molal thermal functions for potassium pentaborate tetrahydrate $\left(\mathrm{KB}_{5} \mathrm{O}_{8} \cdot 4 \mathrm{H}_{2} \mathrm{O}\right)$

Gram molecular weight $=293.214 \mathrm{~g}, T$ deg $\mathrm{K}=t \operatorname{deg} \mathrm{C}+273.15$

\begin{tabular}{|c|c|c|c|c|c|c|}
\hline$T$ & $C_{P}$ & $\left(H_{T}-H_{\mathrm{O}}^{\mathrm{C}}\right)$ & $\frac{\left(H_{T}-H_{\mathrm{O}}^{\mathrm{C}}\right)}{T}$ & $S_{T}$ & $-\left(G_{T}-H_{\mathrm{O}}^{\mathrm{C}}\right)$ & $\frac{-\left(G_{T}-H_{\mathrm{O}}^{\mathrm{C}}\right)}{T}$ \\
\hline${ }^{\circ} K$ & $J /$ deg & $J$ & $J / d e g$ & $J /$ deg & $J$ & $J / \operatorname{deg}$ \\
\hline 0.00 & 0.000 & 0.000 & 0.000 & 0.000 & 0.000 & 0.000 \\
\hline 5.00 & .308 & .385 & .077 & .103 & .128 & .026 \\
\hline 10.00 & 2.460 & 6.163 & .616 & .822 & 2.055 & .205 \\
\hline 15.00 & 7.871 & 30.557 & 2. 037 & 2. 727 & 10.341 & .689 \\
\hline 20.00 & 15.959 & 89.428 & 4. 471 & 6. 058 & 31.730 & 1. 586 \\
\hline 25.00 & 25.240 & 191.96 & 7.678 & 10.595 & 72.921 & 2. 917 \\
\hline 30.00 & 35.285 & 343.14 & 11.438 & 16.080 & 139.26 & 4. 642 \\
\hline 35.00 & 45.729 & 545.59 & 15.588 & 22.301 & 234. 94 & 6.713 \\
\hline 40.00 & 55.941 & 799.91 & 19. 998 & 29. 078 & 363.20 & 9.080 \\
\hline 45.00 & 65.891 & 1104.6 & 24.548 & 36.245 & 526.37 & 11.697 \\
\hline 50.00 & 75.439 & 1458.2 & 29.164 & 43.686 & 726.10 & 14.522 \\
\hline 55.00 & 84.423 & 1858.2 & 33. 785 & 51.303 & 963.53 & 17.519 \\
\hline 60.00 & 92.753 & 2301.3 & 38.355 & 59.010 & 1239.3 & 20.655 \\
\hline 65.00 & 100.72 & 2785.2 & 42.850 & 66.752 & 1553.7 & 23. 903 \\
\hline 70.00 & 107.85 & 3306.9 & 47.241 & 74.481 & 1906.8 & 27. 240 \\
\hline 75.00 & 114.70 & 3863.4 & 51.512 & 82.157 & 2298.4 & 30.645 \\
\hline 80.00 & 121.37 & 4453.6 & 55.670 & 89. 773 & 2728.2 & 34.103 \\
\hline 85.00 & 127.90 & 5077.0 & 59. 729 & 97.329 & 3196.0 & 37. 600 \\
\hline 90.00 & 133.79 & 5731.4 & 63.682 & 104.81 & 3701.4 & 41.127 \\
\hline 95.00 & 139.39 & 6414.5 & 67.521 & 112.19 & 4244.0 & 44.673 \\
\hline 100.00 & 144.88 & 7125.2 & 71.252 & 119.48 & 4823.2 & 48.232 \\
\hline 105.00 & 150.27 & 7863.1 & 74.887 & 126.68 & 5438.6 & 51. 797 \\
\hline 110.00 & 155.56 & 8627.7 & 78.434 & 133.80 & 6089.9 & 55.363 \\
\hline 115.00 & 160.75 & 9418.5 & 81.900 & 140.83 & 6776.5 & 58. 926 \\
\hline 120.00 & 165.83 & 10235 & 85.292 & 147.78 & 7498.0 & 62.483 \\
\hline 125.00 & 170.88 & 11077 & 88.615 & 154.65 & 8254.1 & 66.033 \\
\hline 130.00 & 175.89 & 11944 & 91.875 & 161.45 & 9044.4 & 69.572 \\
\hline 135.00 & 180.88 & 12836 & 95.080 & 168.18 & 9868.5 & 73.100 \\
\hline 140.00 & 185.84 & 13753 & 98.232 & 174.85 & 10726 & 76.615 \\
\hline 145.00 & 190.78 & 14694 & 101.34 & 181.45 & 11617 & 80.116 \\
\hline 150.00 & 195.68 & 15660 & 104.40 & 188.01 & 12541 & 83.603 \\
\hline 155.00 & 200.55 & 16651 & 107.43 & 194.50 & 13497 & 87.076 \\
\hline 160.00 & 205. 39 & 17666 & 110.41 & 200.95 & 14485 & 90.534 \\
\hline 165.00 & 210.19 & 18705 & 113. 36 & 207.34 & 15506 & 93.977 \\
\hline 170.00 & 214.95 & 19768 & 116.28 & 213.68 & 16559 & 97.404 \\
\hline 175.00 & 219. 70 & 20854 & 119.17 & 219.98 & 17643 & 100.82 \\
\hline 180.00 & 224.38 & 21964 & 122.02 & 226.24 & 18759 & 104. 21 \\
\hline 185.00 & 229.05 & 23098 & 124.85 & 232.45 & 19905 & 107.60 \\
\hline 190.00 & 233. 68 & 24255 & 127.66 & 238.62 & 21083 & 10096 \\
\hline 195.00 & 238.30 & 25435 & 130.44 & 244.75 & 22291 & 114.31 \\
\hline 200.00 & 242.90 & 26638 & 133.19 & 250.84 & 23530 & 117.65 \\
\hline 205. 00 & 247.51 & 27864 & 135. 92 & 256.90 & 24800 & 120.97 \\
\hline 210.00 & 252.13 & 29113 & 138.63 & 262.92 & 26099 & 124.28 \\
\hline 215.00 & 256.74 & 30385 & 141.33 & 268.90 & 27429 & 127.58 \\
\hline 220.00 & 261.34 & 31680 & 144.00 & 274.86 & 28788 & 130.86 \\
\hline 225.00 & 265.92 & 32999 & 146.66 & 280.78 & 30177 & 134.12 \\
\hline 230.00 & 270.49 & 34340 & 149.30 & 286.68 & 31596 & 137.37 \\
\hline 235.00 & 275.03 & 35703 & 151.93 & 292.54 & 33044 & 140.61 \\
\hline 240.00 & 279.55 & 37090 & 154.54 & 298. 38 & 34521 & 143.84 \\
\hline 245.00 & 284.05 & 38499 & 157.14 & 304.19 & 36028 & 147.05 \\
\hline 250.00 & 288.53 & 39930 & 159.72 & 309.97 & 37563 & 150.25 \\
\hline 255.00 & 292.98 & 41384 & 162.29 & 315.73 & 39128 & 153.44 \\
\hline 260.00 & 297.41 & 42860 & 164.85 & 321.46 & 40720 & 156.62 \\
\hline 265.00 & 301.82 & 44358 & 167.39 & 327.17 & 42342 & 159.78 \\
\hline 270.00 & 306.21 & 45878 & 169. 92 & 332.85 & 43992 & 162.93 \\
\hline 273.15 & 308.96 & 46847 & 171.51 & 336.42 & 45046 & 164.91 \\
\hline 275.00 & 310.57 & 47420 & 172.44 & 338.51 & 45671 & 166.07 \\
\hline 280.00 & 314.91 & 48984 & 174. 94 & 344.15 & 47377 & 169.20 \\
\hline 285.00 & 319.23 & 50569 & 177.44 & 349.76 & 49112 & 172.32 \\
\hline 290.00 & 323.52 & 52176 & 179. 92 & 355.35 & 50875 & 175.43 \\
\hline 295.00 & 327.79 & 53804 & 182.39 & 360.91 & 52665 & 178.53 \\
\hline 298.15 & 330.48 & 54841 & 183.94 & 364.41 & 53808 & 180.47 \\
\hline 300.00 & 332.05 & 55454 & 184.85 & 366.46 & 54484 & 181.61 \\
\hline 305.00 & 336.29 & 57125 & 187.29 & 371.98 & 56330 & 184.6 \\
\hline 310.00 & 340.51 & 58817 & 189.73 & 377.49 & 58204 & 187.75 \\
\hline 315.00 & 344.70 & 60530 & 192.16 & 382.97 & 60105 & 190.81 \\
\hline 320.00 & 348.88 & 62264 & 194.57 & 388.43 & 62033 & 193.85 \\
\hline 325.00 & 353. 03 & 64019 & 196.98 & 393.87 & 63989 & 196.89 \\
\hline 330.00 & 357.16 & 65794 & 199. 38 & 399.29 & 65972 & 199. 92 \\
\hline 335.00 & 361.26 & 67590 & 201.76 & 404.69 & 67982 & 202.93 \\
\hline 340.00 & 365.35 & 69407 & 204.14 & 410.07 & 70019 & 205. 94 \\
\hline 345.00 & 369.41 & 71243 & 206.50 & 415.44 & 72083 & 208. 94 \\
\hline 350.00 & 373.45 & 73101 & 208.86 & 420.78 & 74173 & 211.92 \\
\hline 355.00 & 377.46 & 74978 & 211.21 & 426.11 & 76290 & 214.90 \\
\hline 360.00 & 381.46 & 76875 & 213.54 & 431.42 & 78434 & 217.87 \\
\hline 365.00 & 385.42 & 78792 & 215.87 & 436. 70 & 80605 & 220.83 \\
\hline 370.00 & 389.37 & 80729 & 218.19 & 441.97 & 82801 & 223. 79 \\
\hline 373.15 & 391.83 & 81960 & 219.64 & 445.29 & 84199 & 225.64 \\
\hline
\end{tabular}

$H_{0}^{\mathrm{C}}$ apply to the reference state of the solid at $0{ }^{\circ} \mathrm{K}$.
TABLE 9. Observed heat capacities of sodium pentaborate pentahydrate $\left(\mathrm{NaB}_{5} \mathrm{O}_{8} .5 \mathrm{H}_{2} \mathrm{O}\right)$

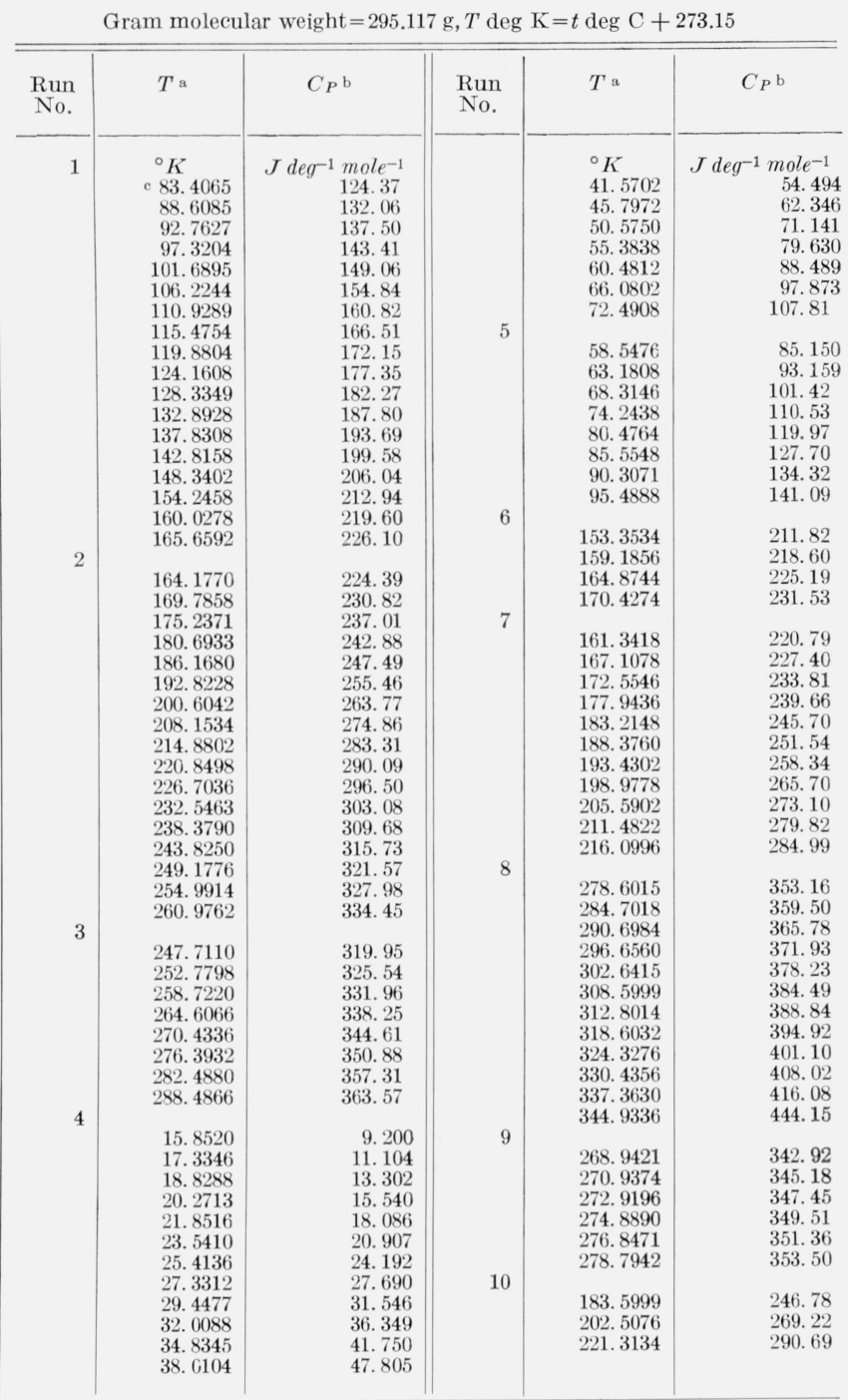

a $T$ is the mean temperature of the heating interval.

b $C_{P}$ is the observed mean heat capacity over the interval.

c The temperatures given are believed to be accurate to $0.01^{\circ} \mathrm{K}$. The figures beyond the second decimal are significant only insofar as small temperature differences are concerned.

followed by a decrease to a limiting value with increasing temperature is to be generally expected.

A calculation similar to those presented earlier by Staveley et al. $[15,16,17]$ was performed with the heat-capacity results obtained on APT and PPT. The results are shown in figure 5. APT and PP'T are both orthorhombic, Aba2- $\mathrm{C}_{2 \mathrm{v}}^{17}$, with crystal constants $a=11.324 \AA, b=11.029 \AA$, and $c=9.235 \AA$ and $a=11.065 \AA$, $b=11.171 \AA$, and $c=9.054 \AA$, respectively [19]. The ionic radius of ammonium ion is $1.48 \AA$ and that of the potassium ion is $1.33 \AA$ [20]. The above crystal constants indicate that the specific volume of PPT is about 3 percent smaller than that of APT. The forces between the cation and anion are, therefore, expected to be somewhat 
TABLE 10. Molal thermal functions for sodium pentaborate pentahydrate $\left(\mathrm{NAB}_{5} \mathrm{O}_{8} \cdot 5 \mathrm{H}_{2} \mathrm{O}\right)$

Gram molecular weight $=295.117 \mathrm{~g}, T \operatorname{deg} \mathrm{K}=t \operatorname{deg} \mathrm{C}+273.15$

\begin{tabular}{|c|c|c|c|c|c|c|}
\hline$T$ & $C_{P}$ & $\left(H_{T}-H_{0}^{C}\right)$ & $\frac{\left(H_{T}-H_{0}^{C}\right)}{T}$ & $S_{T}$ & $-\left(G_{T}-H_{0}^{C}\right)$ & $\frac{-\left(G_{T}-H_{0}^{C}\right)}{T}$ \\
\hline${ }^{\circ} K$ & $J / d e g$ & $J$ & $J /$ deg & $J /$ deg & $J$ & $J /$ deg \\
\hline 0.00 & 0.000 & 0.000 & 0.000 & 0.000 & 0.000 & 0.000 \\
\hline $\begin{array}{r}5.00 \\
10.00 \\
15.00 \\
20.00 \\
25.00\end{array}$ & $\begin{array}{r}.303 \\
2.412 \\
7.658 \\
15.102 \\
23.425\end{array}$ & $\begin{array}{r}.378 \\
6.046 \\
29.873 \\
86.499 \\
182.40\end{array}$ & $\begin{array}{r}.076 \\
.605 \\
1.992 \\
4.325 \\
7.296\end{array}$ & $\begin{array}{r}.101 \\
.806 \\
2.667 \\
5.874 \\
10.119\end{array}$ & $\begin{array}{r}.126 \\
2.017 \\
10.136 \\
30.976 \\
70.581\end{array}$ & $\begin{array}{r}.025 \\
.202 \\
.676 \\
1.549 \\
2.823\end{array}$ \\
\hline $\begin{array}{l}30.00 \\
35.00 \\
40.00 \\
45.00 \\
50.00\end{array}$ & $\begin{array}{l}32.552 \\
42.084 \\
51.526 \\
60.857 \\
70.088\end{array}$ & $\begin{array}{c}322.21 \\
508.60 \\
742.67 \\
1023.7 \\
1351.2\end{array}$ & $\begin{array}{l}10.740 \\
14.531 \\
18.567 \\
22.749 \\
27.023\end{array}$ & $\begin{array}{l}15.192 \\
20.920 \\
27.157 \\
33.766 \\
40.658\end{array}$ & $\begin{array}{l}133.55 \\
223.59 \\
343.60 \\
495.77 \\
681.73\end{array}$ & $\begin{array}{r}4.452 \\
6.388 \\
8.590 \\
11.017 \\
13.635\end{array}$ \\
\hline $\begin{array}{l}55.00 \\
60.00 \\
65.00 \\
70.00 \\
75.00\end{array}$ & $\begin{array}{c}78.950 \\
87.643 \\
96.143 \\
104.00 \\
111.63\end{array}$ & $\begin{array}{l}1723.8 \\
2140.4 \\
2600.0 \\
3100.6 \\
3639.7\end{array}$ & $\begin{array}{l}31.342 \\
35.673 \\
40.000 \\
44.294 \\
48.529\end{array}$ & $\begin{array}{l}47.755 \\
54.998 \\
62.352 \\
69.767 \\
77.203\end{array}$ & $\begin{array}{c}902.69 \\
1159.5 \\
1452.9 \\
1783.1 \\
2150.6\end{array}$ & $\begin{array}{l}16.413 \\
19.325 \\
22.352 \\
25.473 \\
28.674\end{array}$ \\
\hline $\begin{array}{r}80.00 \\
85.00 \\
90.00 \\
95.00 \\
100.00\end{array}$ & $\begin{array}{l}119.24 \\
126.87 \\
133.89 \\
140.41 \\
146.88\end{array}$ & $\begin{array}{l}4216.9 \\
4832.3 \\
5484.4 \\
6170.3 \\
6888.5\end{array}$ & $\begin{array}{l}52.711 \\
56.850 \\
60.938 \\
64.950 \\
68.885\end{array}$ & $\begin{array}{c}84.651 \\
92.110 \\
99.563 \\
106.98 \\
114.35\end{array}$ & $\begin{array}{l}2555.2 \\
2997.1 \\
3476.3 \\
3992.7 \\
4546.0\end{array}$ & $\begin{array}{l}31.940 \\
35.260 \\
38.625 \\
42.028 \\
45.460\end{array}$ \\
\hline $\begin{array}{l}105.00 \\
110.00 \\
115.00 \\
120.00 \\
125.00\end{array}$ & $\begin{array}{l}153.30 \\
159.64 \\
165.94 \\
172.11 \\
178.23\end{array}$ & $\begin{array}{c}7639.0 \\
8421.3 \\
9235.3 \\
10080 \\
10956\end{array}$ & $\begin{array}{l}72.752 \\
76.558 \\
80.307 \\
84.004 \\
87.651\end{array}$ & $\begin{array}{l}121.67 \\
128.94 \\
136.18 \\
143.37 \\
150.52\end{array}$ & $\begin{array}{l}5136.0 \\
5762.6 \\
6425.4 \\
7124.3 \\
7859.1\end{array}$ & $\begin{array}{l}48.915 \\
52.387 \\
55.873 \\
59.369 \\
62.873\end{array}$ \\
\hline $\begin{array}{l}130.00 \\
135.00 \\
140.00 \\
145.00 \\
150.00\end{array}$ & $\begin{array}{l}184.30 \\
190.29 \\
196.23 \\
202.11 \\
207.96\end{array}$ & $\begin{array}{l}11863 \\
12799 \\
13766 \\
14761 \\
15787\end{array}$ & $\begin{array}{c}91.252 \\
94.809 \\
98.326 \\
101.80 \\
105.24\end{array}$ & $\begin{array}{l}157.63 \\
164.70 \\
171.73 \\
178.72 \\
185.67\end{array}$ & $\begin{array}{c}8629.5 \\
9435.3 \\
10276 \\
11153 \\
12064\end{array}$ & $\begin{array}{l}66.381 \\
69.891 \\
73.403 \\
76.914 \\
80.424\end{array}$ \\
\hline $\begin{array}{l}155.00 \\
160.00 \\
165.00 \\
170.00 \\
175.00\end{array}$ & $\begin{array}{l}213.76 \\
219.51 \\
225.18 \\
230.83 \\
236.48\end{array}$ & $\begin{array}{l}16841 \\
17924 \\
19036 \\
20176 \\
21344\end{array}$ & $\begin{array}{l}108.65 \\
112.03 \\
115.37 \\
118.68 \\
121.97\end{array}$ & $\begin{array}{l}192.58 \\
199.46 \\
206.30 \\
213.11 \\
219.88\end{array}$ & $\begin{array}{l}13009 \\
13989 \\
15004 \\
16052 \\
17135\end{array}$ & $\begin{array}{l}83.930 \\
87.433 \\
90.932 \\
94.425 \\
97.913\end{array}$ \\
\hline $\begin{array}{l}180.00 \\
185.00 \\
190.00 \\
195.00 \\
200.00\end{array}$ & $\begin{array}{l}242.12 \\
247.74 \\
253.56 \\
259.78 \\
266.07\end{array}$ & $\begin{array}{l}22541 \\
23765 \\
25018 \\
20302 \\
27616\end{array}$ & $\begin{array}{l}125.23 \\
128.46 \\
131.68 \\
134.88 \\
138.08\end{array}$ & $\begin{array}{l}226.62 \\
233.33 \\
240.01 \\
246.68 \\
253.34\end{array}$ & $\begin{array}{l}18251 \\
19401 \\
20594 \\
21801 \\
23051\end{array}$ & $\begin{array}{l}101.39 \\
104.87 \\
108.34 \\
111.80 \\
115.26\end{array}$ \\
\hline $\begin{array}{l}205.00 \\
210.00 \\
215.00 \\
220.00 \\
225.00\end{array}$ & $\begin{array}{l}272.33 \\
278.15 \\
283.81 \\
289.39 \\
294.98\end{array}$ & $\begin{array}{l}28962 \\
30339 \\
31744 \\
33177 \\
34638\end{array}$ & $\begin{array}{l}141.28 \\
144.47 \\
147.65 \\
150.80 \\
153.95\end{array}$ & $\begin{array}{l}259.98 \\
266.62 \\
273.23 \\
279.82 \\
286.38\end{array}$ & $\begin{array}{l}24334 \\
25651 \\
27000 \\
28383 \\
29799\end{array}$ & $\begin{array}{l}118.70 \\
122.15 \\
125.58 \\
129.01 \\
132.44\end{array}$ \\
\hline $\begin{array}{l}230.00 \\
235.00 \\
240.00 \\
245.00 \\
250.00\end{array}$ & $\begin{array}{l}300.53 \\
306.06 \\
311.56 \\
317.03 \\
322.48\end{array}$ & $\begin{array}{l}36126 \\
37643 \\
39187 \\
40759 \\
42357\end{array}$ & $\begin{array}{l}157.07 \\
160.18 \\
163.28 \\
166.36 \\
169.43\end{array}$ & $\begin{array}{l}292.93 \\
299.45 \\
305.95 \\
312.43 \\
318.89\end{array}$ & $\begin{array}{l}31247 \\
32728 \\
34241 \\
35787 \\
37366\end{array}$ & $\begin{array}{l}135.86 \\
139.27 \\
142.67 \\
146.07 \\
149.46\end{array}$ \\
\hline $\begin{array}{l}255.00 \\
260.00 \\
265.00 \\
270.00 \\
273.15\end{array}$ & $\begin{array}{l}327.90 \\
333.30 \\
338.66 \\
344.01 \\
347.36\end{array}$ & $\begin{array}{l}43983 \\
45636 \\
47316 \\
49023 \\
50112\end{array}$ & $\begin{array}{l}172.48 \\
175.52 \\
178.55 \\
181.57 \\
183.46\end{array}$ & $\begin{array}{l}325.33 \\
331.75 \\
338.15 \\
344.53 \\
348.54\end{array}$ & $\begin{array}{l}38976 \\
40619 \\
42294 \\
44000 \\
45092\end{array}$ & $\begin{array}{l}152.85 \\
156.23 \\
159.60 \\
162.96 \\
165.08\end{array}$ \\
\hline $\begin{array}{l}275.00 \\
280.00 \\
285.00 \\
290.00 \\
295.00\end{array}$ & $\begin{array}{l}349.33 \\
354.62 \\
359.87 \\
365.14 \\
370.28\end{array}$ & $\begin{array}{l}50756 \\
52516 \\
54302 \\
56115 \\
57953\end{array}$ & $\begin{array}{l}184.57 \\
187.56 \\
190.53 \\
193.50 \\
196.45\end{array}$ & $\begin{array}{l}350.89 \\
357.23 \\
363.56 \\
369.86 \\
376.15\end{array}$ & $\begin{array}{l}45739 \\
47509 \\
49311 \\
51145 \\
53010\end{array}$ & $\begin{array}{l}166.32 \\
169.68 \\
173.02 \\
176.36 \\
179.69\end{array}$ \\
\hline $\begin{array}{l}298.15 \\
300.00 \\
305.00 \\
310.00 \\
315.00\end{array}$ & $\begin{array}{l}373.55 \\
375.47 \\
380.68 \\
385.91 \\
391.17\end{array}$ & $\begin{array}{l}59125 \\
59818 \\
61708 \\
63625 \\
65567\end{array}$ & $\begin{array}{l}198.31 \\
199.39 \\
202.32 \\
205.24 \\
208.15\end{array}$ & $\begin{array}{l}380.10 \\
382.41 \\
388.66 \\
394.90 \\
401.11\end{array}$ & $\begin{array}{l}54201 \\
54906 \\
56834 \\
58793 \\
60783\end{array}$ & $\begin{array}{l}181.79 \\
183.02 \\
186.34 \\
189.65 \\
192.96\end{array}$ \\
\hline $\begin{array}{l}320.00 \\
325.00 \\
330.00 \\
335.00 \\
340.00\end{array}$ & $\begin{array}{l}396.50 \\
401.96 \\
407.52 \\
413.24 \\
419.05\end{array}$ & $\begin{array}{l}67536 \\
69533 \\
71556 \\
73608 \\
75689\end{array}$ & $\begin{array}{l}211.05 \\
213.95 \\
216.84 \\
219.73 \\
222.61\end{array}$ & $\begin{array}{l}407.31 \\
413.50 \\
419.68 \\
425.85 \\
432.02\end{array}$ & $\begin{array}{l}62804 \\
64856 \\
66939 \\
69053 \\
71197\end{array}$ & $\begin{array}{l}196.26 \\
199.56 \\
202.85 \\
206.13 \\
209.40\end{array}$ \\
\hline 345.00 & 424.75 & 77798 & 225.50 & 438.18 & 73373 & 212.68 \\
\hline
\end{tabular}

$H_{0}^{C}$ apply to the reference state of the solid at $0{ }^{\circ} \mathrm{K}$.

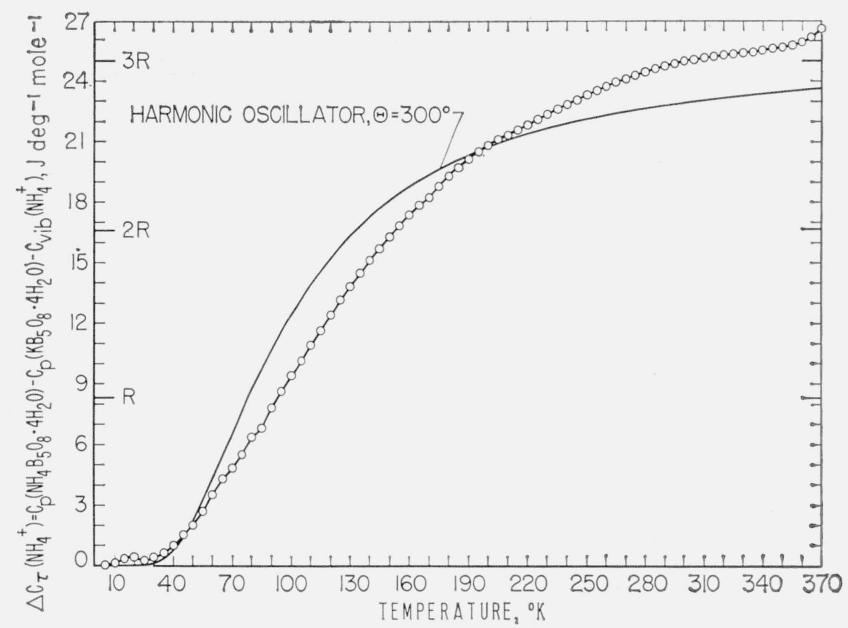

Figure 5. Heat capacity from the torsional or rotational motions of $\mathrm{NH}_{4}{ }^{+}$ion and the heat capacity of a harmonic oscillator.

different in the two salts, and the assumptions regarding the similarity in the contributions to the heat capacity other than from $\Delta C_{\tau}\left(\mathrm{NH}_{4}{ }^{+}\right)$may not be completely valid. The internal and torsional motions of the anion and the water of hydration may be significantly different in the two salts. The rubidium ion with an ionic radius of $1.48 \AA$ [20] would be expected to form a salt with crystal constants close to those of the ammonium salt.

The results in the region of the upper temperature limit of measurements shown in figure 5 suggest that the $\Delta C_{\tau}\left(\mathrm{NH}_{4}^{+}\right)$in $\mathrm{AP} T$ approximates the value $3 R$ of a fully excited classical torsional oscillator. The results reported by Staveley et al. $[15,16,17]$ on ammonium and rubidium salts of tetraphenylboron, stannic chloride, stannic bromide, and hexafluorophosphate are considerably below the $3 R$ value. In the tetraphenylboron salt [17] the $\Delta C_{\tau}\left(\mathrm{NH}_{4}{ }^{+}\right)$ is shown to be about $\frac{5}{2} R$ at $300^{\circ} \mathrm{K}$, the upper limit of their measurements, and increasing. The $\Delta C_{\tau}$ $\left(\mathrm{NH}_{4}{ }^{+}\right)$of both ammonium stannic chloride and stannic bromide is shown to have a maximum followed by an asymptotic decrease with temperature [16] related to a hindered rotator behavior.

If heat-capacity measurements were made on rubidium pentaborate tetrahydrate (RP'T) and the results used to calculate $\Delta C_{\tau}\left(\mathrm{NH}_{4}{ }^{+}\right)$the values in the upper temperature region are expected to be higher than those shown in figure 5. The results of the heatcapacity measurements of Davies and Staveley [17] on ammonium, potassium, and rubidium salts of tetraphenylboron show that above $200{ }^{\circ} \mathrm{K}$ the heat capacity of the potassium salt is higher than that of the rubidium salt. The measurements of Morfee et al., [16] show also that the heat capacity of potassium stannic bromide is greater at the higher temperatures (above about $100^{\circ} \mathrm{K}$ ) than that of the corresponding rubidium salt. The considerably higher values than $3 R$ expected for $\Delta \mathrm{C}_{\tau}\left(\mathrm{NH}_{4}{ }^{+}\right)$, if the heat capacity of RPT were used instead, would 
indicate that the values close to $3 R$ obtained for $\Delta C_{\tau}\left(\mathrm{NH}_{4}^{+}\right)$with $\mathrm{AP}$ T and PP' measurements are fortuitous. For the simpler salts, for example the bromides [21], iodides [21], and acid fluorides [22, 23 , the heat capacities of the rubidium salts are higher than those of the potassium salts. Therefore, it seems that the heat-capacity contributions from the various sources in complex salts, such as those of the pentaborate, are dependent in a complicated way on, among others, the cation present.

The $\Delta C_{\tau}\left(\mathrm{NH}_{4}{ }^{+}\right)$obtained was compared with the heat capacity of a harmonic oscillator. Although the $\mathrm{NH}_{4}^{+}$ion in APT is in an asymmetric environment, the best average frequency was determined. In figure 5 the Einstein heat capacity with $\theta=300$ deg is compared with $\Delta C_{\tau}\left(\mathrm{NH}_{4}^{+}\right)$. The values of $\Delta C_{\tau}\left(\mathrm{NH}_{4}^{+}\right)$differ by +100 percent at $10^{\circ} \mathrm{K}$ and +8 percent at $300{ }^{\circ} \mathrm{K}$. It is seen that $\Delta C_{\tau}\left(\mathrm{NH}_{4}{ }^{+}\right)$ behaves considerably different from the heat capacity of a simple torsional oscillator. An attempt was also made to fit the $\Delta C_{\tau}\left(\mathrm{NH}_{4}{ }^{+}\right)$values obtained by Davies and Staveley [17] on ammonium tetraphenylboron, where the $\mathrm{NH}_{4}^{+}$ion is in a more symmetric environment, with the heat capacity of a harmonic oscillator. Although the agreement is better, the discrepancies indicate that the oscillation is not simple and that the heat-capacity contributions for the constituents of a system are affected in a complicated way by any substituent.

The authors are indebted to Rolf A. Paulson of the Analysis and Purification Section for the chemical analyses on the samples. The gift of the samples investigated, by the Pacific Coast Borax Company, through the courtesy of M. H. Pickard, is gratefully acknowledged.

\section{References}

[1] J. O. Edwards and V. Ross, J. Inorg. Nucl. Chem. 15, 329 (1960).

[2] A. A. Silvidi and J. W. McGrath, J. Chem. Phys. 30, $1028(1959)$

[3] P. H. Kemp, The Chemistry of Borates. Part I, Borax Consolidated Limited, London (1956).

[4] J. Krogh-Moe, Acta Cryst. 14, 68 (1961).

[5] R. B. Scott, C. H. Meyers, R. D. Rands, Jr., F. G. Brickwedde, and N. Bekkedahl, J. Res. NBS 35, 39 (1945).

[6] H. F. Stimson, J. Res. NBS 65A, 139 (1961)

[7] H. J. Hoge and F. G. Brickwedde, J. Res. NBS 22, 351 (1939).

[8] IUPAC revises atomic weight values, Chem. Eng. News 39, 42 (1961).

[9] G. T. Furukawa, T. B. Douglas, R. E. McCoskey, and D. C. Ginnings, J. Res. NBS 57, 67 (1956).

[10] E. Whittaker and G. Robinson, The calculus of observations, A Treatise on Numerical Mathematics (Blackie and Son, London and Glasgow, 1944).

[11] G. T. Furukawa, D. C. Ginnings, R. E. McCoskey, and R. A. Nelson, J. Res. NBS 46, 195 (1951).

[12] A. F. Ievin'sh, E. M. Shvarts, and Ya. K. Ozol, Zhurn. Neorgan. Khim. 1, 2236 (1956).

[13] H. L. Johnston and E. C. Kerr, J. Am. Chem. Soc. $\boldsymbol{q}$, $4733(1950)$.

[14] W. C. Blasdale and C. M. Slansky, J. Am. Chem. Soc. 61, 917 (1939)

[15] L. A. K. Staveley, N. R. Grey, and M. J. Layzell, Zeit. Naturforschg. 18A, 148 (1963)

[16] R. G. S. Morfee, L. A. K. Staveley, S. T. Walters, and D. L. Wigley, J. Phys. Chem. Solids 13, 132 (1960).

[17] T. Davies and L. A. K. Staveley, Trans. Faraday Sce. 53, 19 (1957).

[18] E. L. Wagner and D. F. Hornig, J. Chem. Phys. 18, $296(1950)$.

[19] W. R. Cook, Jr., and H. Jaffe, Acta Cryst. 10, 705 (1957).

[20] L. Pauling, The Nature of the Chemical Bond and the Structure of Molecules and Crystals: An Introduction to Modern Structure Chemistry, Third Edition, Cornell University Press (1960).

[21] K. Clusius, J. Goldmann and A. Perlick, Zeit. Naturforsch. 4A, 424 (1949).

[22] E. F. Westrum, Jr., and K. S. Pitzer, J. Am. Chem. Soc. 71, $1940(1949)$

[23] G. A. Burney and E. F. Westrum, Jr., J. Phys. Chem. 65, 349 (1961). 